\title{
A serpulid-Anodontia-dominated methane-seep deposit from the upper Miocene of northern Italy
}

\author{
Steffen Kiel, Marco Sami, and Marco Taviani \\ Acta Palaeontologica Polonica 63 (3), 2018: 569-577 doi:https://doi.org/10.4202/app.00472.2018
}

A limestone deposit with an unusual fauna is reported from the late Miocene of northern Italy $(\mathrm{Ca}$ ' Fornace site). The petrography of the carbonate and its distinct carbon isotope signature (with $\delta 13 \mathrm{C}$ values as low as $-\mathbf{5 7 . 6 \% o}$ ) clearly identify this limestone as an ancient methane-seep deposit. The dominant faunal elements are serpulid tubes belonging to Protis, and extremely inflated, medium-sized shells of the lucinid bivalve Anodontia mioinflata sp. nov. Also common is the small bathymodiolin Idas aff. tauroparva, plus some large specimens of the lucinid Lucinoma , and poorly preserved, medium-sized specimens of a possible vesicomyid bivalve, an arcid bivalve, small gastropods of the genera Laeviphitus (Elachisinidae), Anatoma (Scissurellidae), as well as desmophyliid and caryophyllid scleractinian corals. This faunal assemblage is quite distinct from the typical Miocene seep faunas in northern Italy, which are dominated by large bivalves of the Lucinidae (Meganodontia), Vesicomyidae (Archivesica), and Bathymodiolinae, possibly due to a shallower depositional depth of the Ca' Fornace site.

Key words: Gastropoda, Scleractinia, Serpulidae, Bivalvia, Lucinidae, Bathymodiolinae, methane seep, Miocene, Italy, Apennines.

Steffen Kiel [steffen.kiel@nrm.se], Swedish Museum of Natural History, Department of Palaeobiology, Box 50007, 10405 Stockholm, Sweden. Marco Sami [marco.sami@ cheapnet.it], Museo Civico di Scienze Naturali, 51, Via Medaglie D’Oro 51, 48018 Faenza, Italy. Marco Taviani [marco.taviani@bo.ismar.cnr.it], Institute of Marine Sciences, Italian National Research Council, Via Gobetti 101, 40129 Bologna, Italy; Biology Department, Woods Hole Oceanographic Institution, 266 Woods Hole Rd, Woods Hole, MA 02543, USA; and Stazione Zoologica Anton Dohrn, Villa Comunale, 80121 Napoli, Italy.

This is an open-access article distributed under the terms of the Creative Commons Attribution License (for details please see creativecommons.org), which permits unrestricted use, 
distribution, and reproduction in any medium, provided the original author and source are credited.

For Full text $(1,031.8 \mathrm{kB})$ 